www.jmscr.igmpublication.org

Impact Factor 5.84

Index Copernicus Value: 71.58

ISSN (e)-2347-176x ISSN (p) 2455-0450

crossref DOI: https://dx.doi.org/10.18535/jmscr/v5i9.47

Journal Of Medical Science And Clinical Research

IGM Publication

An Official Publication of IGM Publication

Original research Article

\title{
Evaluation of Urinary Albumin Level in Newly Diagnosed Hypertensive Patients for Early Digonosis of Renal Diseases in Rural Area of Rajasthan
}

\author{
Authors \\ Kush Manna', Pankaj Kumar Meena ${ }^{2}$, Gajendra Singh Meena ${ }^{3}$, Himani Agrawal ${ }^{4}$, \\ Laxminarayan Meena ${ }^{5}$, Gagan Priya Pandey ${ }^{6}$ \\ ${ }^{1}$ Demostrator, Dept of Biochemistry, World College of Medical Science \& Research, Jhajjar (Haryana) \\ 2,3,4,5 PG Students, Department of Biochemistry, NIMS Medical College \& Hospital, Jaipur (Rajasthan) \\ ${ }^{6}$ Assistant Professor, Department of Microbiology, NIMS Institute of Paramedical Science \& Technology, \\ NIMS University, Jaipur (Rajasthan)
}

\begin{abstract}
Now-a-days, Hypertension is worldwide threat. For the detection of early renal disease, proteinuria play the important role. Specially, urine albumin is important to find out early renal diseases. For the present study, a total 100 newly diagnosed hypertensive patients were detected along with same no. of healthy individuals, having same aged grouped between 25-65 years were taken as control. Test for detection of urine protein through calorimetery method by total urinary protein detection. Male have higher value than female patients for determination of newly hypertensive patients. The value of urine albumin in newly diagnosed was significant higher than that of the control group. The elevation of the urine albumin is important for the diagnosis of renal disease in newly hypertensive patients. The present study helped to detect the renal damage in newly hypertensive patients and in the rural region of Rajasthan a high intake protein diet has been taken in their meal which should be checked and a balance diet should be taken.

Keywords: Hypertension, Urine Protein, Proteinuria, Renal Diseases.
\end{abstract}

\section{INTRODUCTION}

Hypertension is a major health problem throughout the world because of its high prevalence and its association with increased risk of cardiovascular disease. Proteinurea especially albumin get filtered and appeared in the urine in hypertensive cases ${ }^{1}$. As the GFR decreases, the basement membrane lost the negative charges of the kidney and lower molecular weight proteins, albumin passes the urine. Proteinuria is the sign of CKD, which can result from diabetes, high blood pressure and diseases that cause inflammation in the kidney ${ }^{2}$. Presence of the excess protein particularly albumin in urine indicates renal disease. The present study aimed to determine the level of urine albumin in newly diagnosed hypertensive patients.

\section{AIM \& OBJECTIVES}

1. To determine the urine albumin level in newly diagnosed hypertensive patients.

2. Interpretation and assessment of renal function. 


\section{MATERIALS AND METHODS}

In the present study 100 patients aged 25 to 65 who were diagnosed as newly hypertensive and were confirmed by the estimation of blood pressure on two accasion and questionnaire, were recruited from medicine OPD and the IPD of NIMS Medical College and Hospital. Same number of healthy patients who were aged and sex matched with the newly hypertensive patients, were selected as the control.

Freshly voided random urine sample has been taken and urine albumin level has been detected.

Normal value of urine albumin is $30-300 \mathrm{mg} / 24$ hrs.

Quantitative determination of total urinary $\operatorname{protein}^{(3)}$ :

Table 1: Reagent Composition

\begin{tabular}{|l|l|l|}
\hline $\mathrm{R}$ & Pyrogallol red & $50 \mathrm{mmol} / \mathrm{L}$ \\
& Sodium molybdate & $0.04 \mathrm{mmol} / \mathrm{L}$ \\
\hline$\mu$ Protein CAL & Albumin / Globulin & $1000 \mathrm{mg} / \mathrm{L}$ \\
& aqueous primary standard & \\
\hline
\end{tabular}

Table 2: Test Procedure

\begin{tabular}{|l|c|c|c|}
\hline Reagents & Blank & Standard & Sample \\
\hline $\mathrm{R}(\mathrm{ml})$ & 1.0 & 1.0 & 1.0 \\
\hline Calibrator $(\mu \mathrm{L})$ & - & 20 & - \\
\hline Sample $(\mu \mathrm{L})$ & - & - & 20 \\
\hline
\end{tabular}

Mix and incubate for $5 \mathrm{~min}$. at 37 degree celcius.

Wavelength $-598 \mathrm{~nm}$.

Read the absorbance of the samples and standard, against the blank. The color is stable for atleast 30 $\min$.

\section{Calculation}

Mg protein / 24 hrs. $=($ Sample $/$ Standard $) \times 1000$ (Standard conc.) x Volume (L) urine 24 hrs.

\section{RESULTS AND DISCUSSION}

Table 3: Comparision of urine protein between control and newly hypertensive group by unpaired t-test.

\begin{tabular}{|l|c|c|c|}
\hline Parameter & $\begin{array}{c}\text { Control group } \\
(\mathrm{n}=100)\end{array}$ & $\begin{array}{c}\text { Newly } \\
\text { Hypertensive } \\
\text { Group }(\mathrm{n}=100)\end{array}$ & $\mathrm{p}$-value \\
\hline $\begin{array}{l}\text { Urinary Protein } \\
(\mathrm{mg} / \mathrm{dl})\end{array}$ & $9.89 \pm 3.92$ & $11.89 \pm 1.66$ & $<0.005$ \\
\hline
\end{tabular}

Values in mean \pm SD.
Figure 1: Comparision of urine protein between control and newly hypertensive group by unpaired t-test.

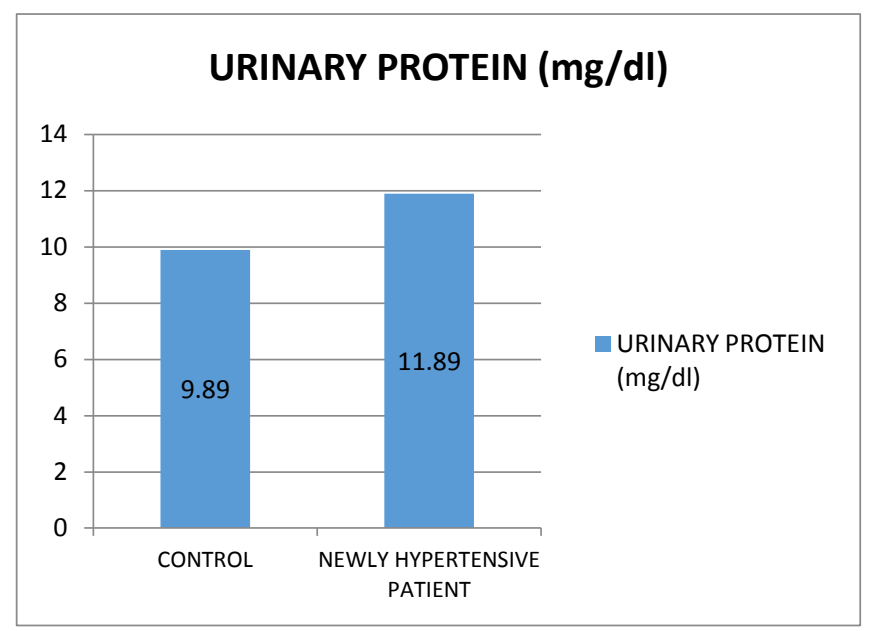

The mean urinary protein concentration which was found in newly hypertensive group was $11.89 \pm 1.66 \mathrm{mg} / \mathrm{dl}$ whereas for control group it's was $9.89 \pm 3.92 \mathrm{mg} / \mathrm{dl}$ and protein excreation in spot urine samples in newly hypertensive group snd control group was found significantly higher, with $p$ value of 0.023 .

Table 4: Comparision of urine protein between male and female newly hypertensive patients.

\begin{tabular}{|l|c|c|}
\hline Total no. of patients & Male & Female \\
\hline 100 & 88 & 12 \\
\hline
\end{tabular}

Figure 2: Comparision of urine protein between male and female newly hypertensive patients.

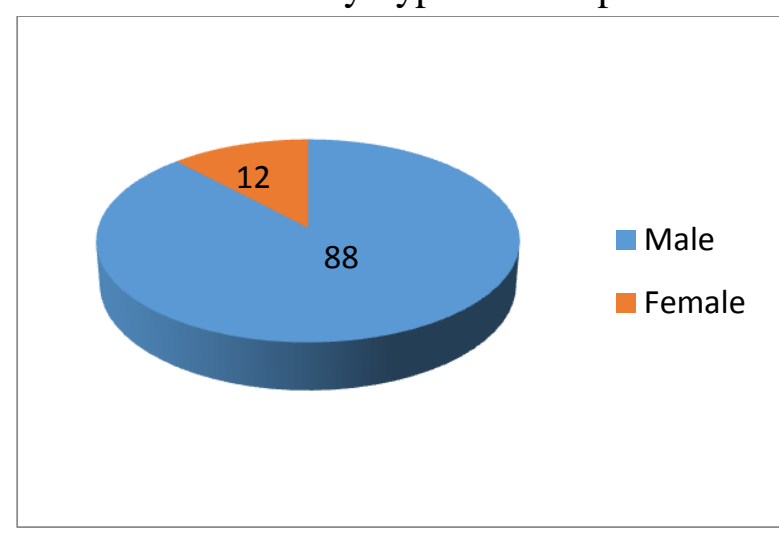

The number of male patients was more than that of female patients having newly diagnosed patients and the value was 88 and 12 respectively. Some investigators advocate the use of albumin as an alternative to the total protein measurements ${ }^{(4,5,6)}$. And others have suggested that the 
profile excreted has differential diagnostic and prognostic value $^{(7)}$. The National Kidney Foundation has recommended that an increased in protein excretion be used as a screening tools in patients at the risk of developing renal disease ${ }^{(8)}$.In the study, the urine protein level of the patients was found to be significantly elevated as compared to the control subjects.

\section{CONCLUSION}

The present study is useful for the determination of early renal disease and help to treat such patients and different methods should be taken to avoid the renal diseases.

\section{REFERENCES}

1. Arthur C. Guyton, John E. Hall. Textbook of Medical Physiology. $11^{\text {th }}$ Edition. Elsevier Publication.409-410.

2. Guh JH. Proteinuria versus albuminuria in chronic kidney diseases. USNLMNIH. 2010; Suppl.2:53-56.

3. Young D S, Effect of Diseases and on Clinical Lab. Tested, $4^{\text {th }}$ Ed., AACC, 2001.

4. Ballantyne FC, Gibbon J, O'reily D. Urine albumin should replace total protein for the assessment of Glomerular Proteinuria. Ann clin Biochem 1993;30:101-103.

5. Beetham R, Cattell WR. Proteinuria: Pathophysiology,

significanceand recommendations in clinical practice. Ann Clin Biochem 1993;30: 425-434.

6. Newman DJ, Thakkar H, Medcalf EA, Gray MR, Price CP. Use of urine albumin measurement as a replacement for total proteinuria. Clin Nephrol1995;43:104-109.

7. Hofmann W, Guder WG. A diagnostic programme for qunantitative analysis of proteinuria. J Clin Chem Biochem 1989; 27:589-600.

8. National Kidney Foundation K/DOQI Clinical practice guidelines for chronic kidney diseases: Elalution, classification and stratification. Amer $\mathrm{J}$ Kidney Dis 2002; 39(2 suppl 1):S1-S266.
ABOUT AUTHORS

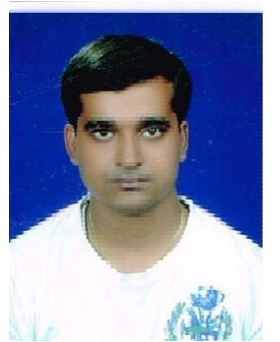

\section{KUSH MANNA}

Demonstrator, Department of Biochemistry, World college of Medical Science and Research, Jhajjar (Haryana). Email: kmanna8@gmail.com

Mo. No.- 8386845876

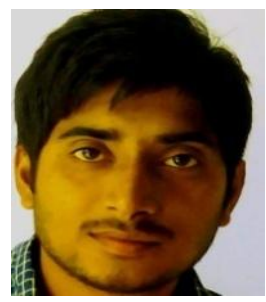

\section{PANKAJ KUMAR MEENA}

Medical Biochemist, Department of Biochemistry, NIMS Medical College and Hospital, Jaipur (Rajasthan)

Email: dr.pankajmeena1989@gmail.com

Mo. No.- 9772909898

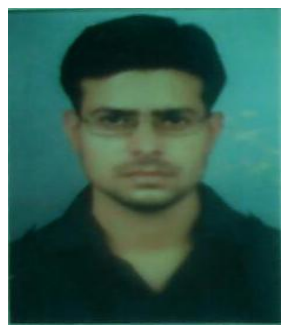

\section{GAJENDER SINGH MEENA MEENA}

Medical Biochemist, Department of Biochemistry, NIMS Medical College and Hospital, Jaipur (Rajasthan). Email: 18gajendersingh@gmail.com Mo. No.- 9660068562

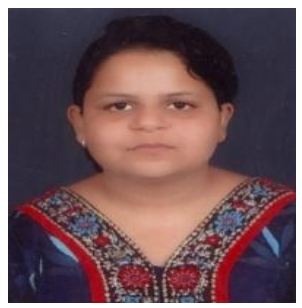

\section{HIMANI AGARWAL}

Medical Biochemist, Department of Biochemistry, NIMS Medical College and Hospital, Jaipur (Rajasthan) Email: agarwal.himani47@gmail.com Mo. No.- 9660651295 


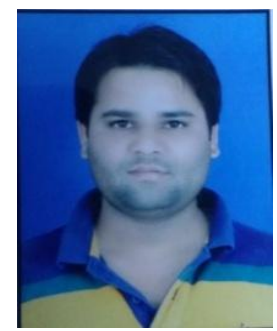

\section{LAXMINARAYAN MEENA}

Medical Biochemist, Department of Biochemistry, NIMS Medical College and Hospital, Jaipur (Rajasthan).

Email: laxminarayan.meena11@gmail.com

Mo. No.- 9660244551

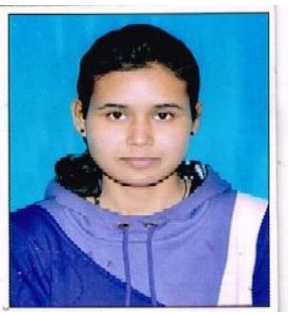

\section{GAGAN PRIYA PANDEY}

Assistant Professor, Department of Microbiology, NIMS Institute of Paramedical Science and Technology, NIMS University, Jaipur (Rajasthan). Email: gaganpandey09@gmail.com Mo. No.- 7689998773 